\title{
CONSUMPTION OF FUEL RESOURCES IN RIVNE REGION
}

\author{
'Iryna OSIPCHUK, ${ }^{2}$ Oksana YAROMENKO \\ 1,2International University of Economics and Humanities named after academician Stepan Demianchuk, Rivne, Ukraine \\ 'osipchukira@ukr.net
}

\begin{abstract}
The article studies modern trends related to the changing patterns of fuel resources consumption in Rivne Region in view of the necessity to dramatically increase the energy efficiency and energy independence for both industrial and consumer economic sectors in Ukrainian regions. Changes in the volumes and share in the consumption structure by different economic sectors have been analyzed for each type of fuels used in Rivne Region. Attention is paid to the territorial distribution and main features of fuel resources use by the administrative units of the Rivne Region, as well as to the dynamics of alternative fuel resources production in the region.
\end{abstract}

Key words: fuel resources, fuel industry, the structure of use of fuel resources.

UDC: 911

\section{ВИКОРИСТАННЯ ПАЛИВНИХ РЕСУРСІВ У РІВНЕНСЬКІЙ ОБЛАСТІ}

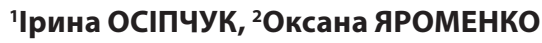 \\ 1,2Міжнародний економіко-гуманітарного університет імені академіка Степана Дем'янчука, Рівне, Україна \\ 'osipchukira@ukr.net
}

\begin{abstract}
Анотація: У статті розглянуто сучасні тенденції щодо зміни структури споживання паливних ресурсів у Рівненській області, що відбуваються у контексті необхідності різкого підвищення рівня енергоефективності та енергонезалежності як промислового, так споживчого сектору економіки регіонів країни. За кожним із видів палива, що використовують на Рівненщині, проаналізовано зміни обсягів та частки у структурі споживання за різними секторами. Розглянуто територіальні особливості розподілу та основних напрямків використання паливних ресурсів за адміністративними одиницями Рівненської області. Також розглянуто перспективи та стан розвитку виробництв альтернативних паливних ресурсів у області.
\end{abstract}

Ключові слова: паливні ресурси, паливна промисловість, структура використання паливних ресурсів.

удк: 911

Вступ. Постановка проблеми. На сучасному етапі розвитку економіки як України загалом, так i Рівненщини зокрема, роль паливних ресурсів постійно зростає. Особливо гостро це питання постало із підвищенням цін на закордонне паливо. Такі тенденції вимагають зміни структури споживання палива, що використовують для потреб населення, промисловості, сільського господарства та інших галузей економіки регіону. На території області діє цілий ряд паливо- та енергоємних промислових виробництв, фінансові результати діяльності яких значно залежать від вартості енергоресурсів, що, у свою чергу, відображається на обсязі податкових надходжень від даних підприємств до місцевих бюджетів, а також впливає на їх здатність утримувати конкурентні позиції на ринках. Підсилює драматичність даної ситуації і відсутність достатніх запасів власних традиційних паливних ресурсів у області.

Аналіз останніх досліджень і публікацій. Дослідженню різних аспектів розвитку та розміщення паливно-енергетичного комплексу присвячені наукові праці багатьох географів, оскільки даний розділ $\epsilon$ складовою географії міжгалузевих комплексів. Протягом останніх років праці, що присвячені енергоефективності та застосуванню альтернативних джерел енергії $\epsilon$ надзвичайно

(C) I. Осіпчук популярними у багатьох наукових напрямках. У розрізі регіональних досліджень паливних ресурсів Рівненщини можна виділити праці Л.В.Мельник, О. А.Пашечки та ін.

Формулювання цілей статті. Постановка завдання. Метою статті є розглянути структуру використання паливних ресурсів у Рівненській області за їх видами та у розрізі адміністративнотериторіальних одиниць. Визначити місце кожного виду паливних ресурсів у господарстві області та прослідкувати зміни, що відбуваються у структурі їх споживання.

Виклад основного матеріалу. За рівнем енергоефективності регіонів України [2] у 2013 році Рівненська область посідала останню 25-ту сходинку із показником $38,5 \%$ від рівня ЄС. У цьому рейтингу Рівненщина займає позиції після Черкаської, Луганської, Полтавської, Харківської областей, тоді як інші області західної частини України розташовуються у першій частині цього списку. Ще у 2011 році у даному рейтингу Рівненщина посідала 21 сходинку, проте наявність застарілого паливоємного виробництва азотних добрив 3 кожним роком погіршує іiї позиції. Так, енергоефективність промисловості Рівненщини становить лише $15 \%$ від рівня $Є С$, що на 35 відсоткових пунктів (в.п.) нижче середнього показника по Україні, тоді як ще у 2011 році цей показник був на рівні $30 \%$. Натомість, у секторі сільського 
господарства Рівненщини енергоефективність відповідає середнім значенням по країні і становить $36,6 \%$ від показника $\mathrm{CC}$, хоча також із 2011 року даний показник знизився на 2,3 в.п. і область втратила аж дев'ять позицій. Натомість, у побутовому секторі Рівненщина посідає аж 5 сходинку із показником енергоефективності 75\% від значення ЄC, що на 13 в.п. вище середнього значення по країні і з 2011 року вона покращила позиції у даному секторі на чотири сходинки, піднявши значення показника на 4 в.п. Це свідчить про наявність суттєвих диспропорції у рівнях розвитку різних секторів економіки області, а також про різну здатність їх адаптуватися до умов, що висувають сучасна ситуація на ринку паливно-енергетичних ресурсів України і світу.

Таким чином, для господарства Рівненської області питання підвищення рівня енергоефективності, насамперед у промисловому секторі, $є$ надзвичайно актуальним. Дослідження структури споживання різних видів палива за секторами економіки регіону, а також сучасних тенденцій у ii зміні дасть можливість більш глибоко зрозуміти ситуацію, що склалася у секторі споживання паливних ресурсів і також допоможе визначити пріоритетні напрямки її диверсифікації.

У структурі витрат енергетичних ресурсів
Рівненщини на продажі для населення припадає $36 \%$, а решта - для використання у господарстві області: найбільше припадає на кінцеве споживання, хоча протягом останніх років даний показник суттєво знизився - із 44,3\% у 2009 році до 39\% у 2013 році. Для перетворення у інші види палива та енергії у 2009 році у області було використано 31,4\% усього палива і до 2013 року даний показник знизився до 26\%. Проте суттєво зросла частка паливних ресурсів, що використовуються як сировина чи матеріали - 3 22,3 до $34 \%$.

Найбільшим споживачем паливних ресурсів у області є промисловість, у якій їх споживають понад $83 \%$.

Всього на Рівненщині у 2013 році було спожито 1208 290,2 т умовного палива, що на 15\% більше ніж у 2009 році. Як видно на рис. 2, найвагоміше місце серед паливних ресурсів, що використовують на Рівненщині, належить природному газу, хоча через постійне підвищення цін на даний вид палива, його частка суттєво скорочується.

У Рівненській області природний газ широко застосовується у всіх сферах господарства, хоча i намагаються скоротити обсяги його споживання. Так, для кінцевого споживання та перетворення у інші види енергій ці обсяги скоротилися майже на третину, натомість суттєво зросло використання

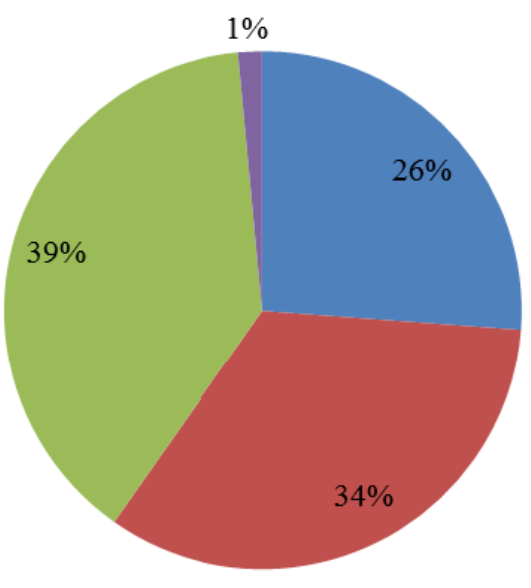

п на перетворення в інші види палива та енергії

пля неенергетичних цілей (як сировина, матеріал)

кінцеве споживання

ш втрати при транспортуванні, розподілі та зберіганні

Рис. 1. Споживання паливних ресурсів у 2013 році за напрямками
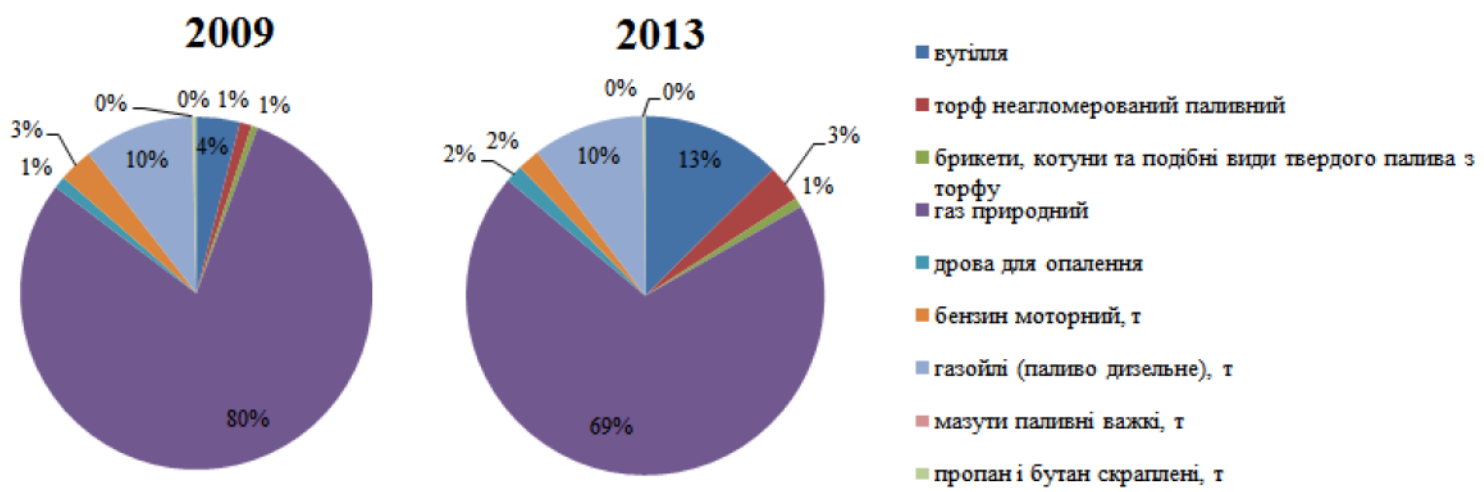

Рис. 2. Споживання окремих видів паливних ресурсів у Рівненській області у перерахунку на умовне паливо (побудовано за [3], [4]) 
природного газу як сировини. Обсяги природного газу, що продають для населення - майже незмінні i y структурі його розподілу займають близько $35 \%$ (рис. 3).

У структурі обсягу використаного у Рівненській області палива (без відпущеного для населення) у перерахунку на умовне паливо частка природного газу становить 74\%: це 75\% для перетворення у інші види енергіï, 99\% із усіх паливних ресурсів, що використовуються як сировина та 6\% - для кінцевого споживання. У господарській діяльності 95\% природного газу припадає на промисловість. Майже 79 \% природного газу у області використовує місто Рівне. Хоча територіальний розподіл із 2009 суттєво змінився: у 2009 році 18\% газу використовував Здолбунівський район, а Рівне $-55 \%$.

На другому місці серед паливних ресурсів, що використовують у Рівненській області знаходиться вугілля. Протягом 2013 року його використовували лише у господарській діяльності і не продавали для населення. У структурі загального обсягу використаного у Рівненській області палива у перерахунку на умовне паливо частка вугілля становить 13\%. Цей показник із 2009 року зріс утричі. Вугілля забезпечує 28\% всього кінцевого споживання та 5\% для перетворення у інші види палива та енергії у області. Хоча ще у 2009 році у кінцевому споживанні його частка становила лише 1\%. Із 2009 року сильно змінилась структура використання вугілля. Основна його частка, а саме $82,5 \%$, припадала на перетворення у інші види палива та енергії, а решта - 17,5\% - на кінцеве споживання. Станом на 2013 рік ситуація стала протилежною: на перетворення у інші види палива припало лише $11 \%$, тоді як на кінцеве споживання аж 89\%. Така зміна структури передусім відбулась за рахунок суттєвого зростання

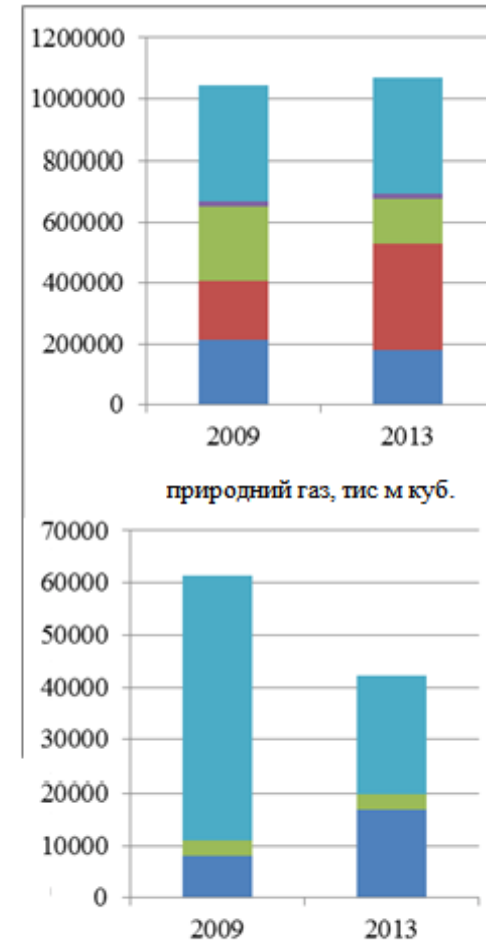

брикети та напівфабрикати торфові, т

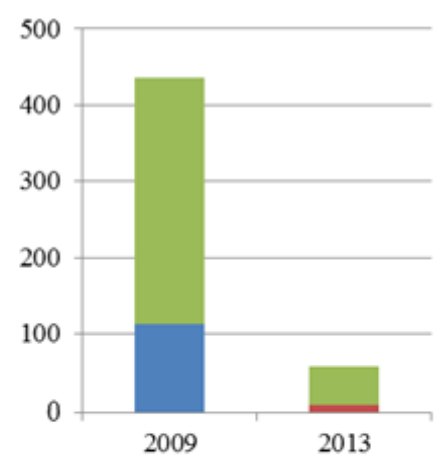

мазути топкові важкі, т

" продаж населенню

= витрати при транспортуванні

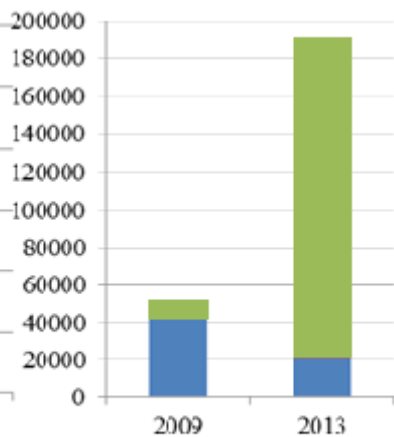

вугілля, $\mathrm{T}$

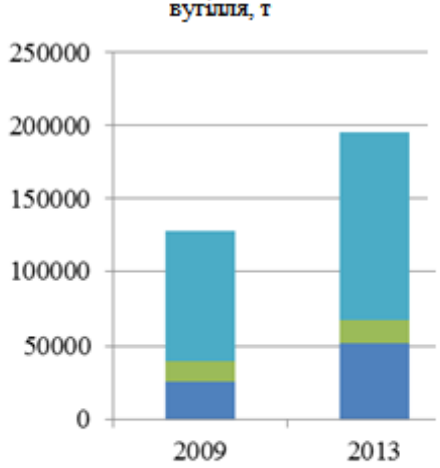

дрова для опалення, м ку6. щільних

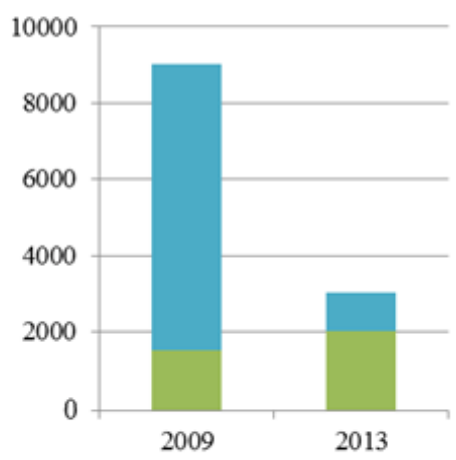

пропан і бутан скраплені, т

" кінцеве споживання

" як сировина, матеріал

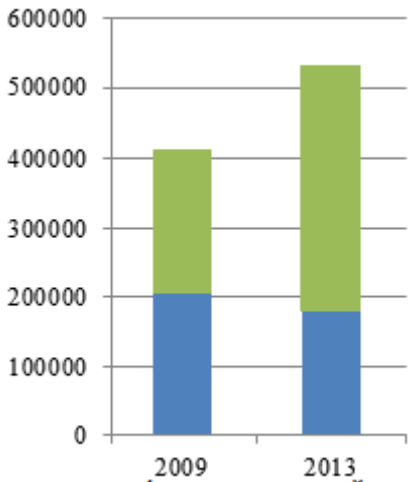

торф неагломерований, т
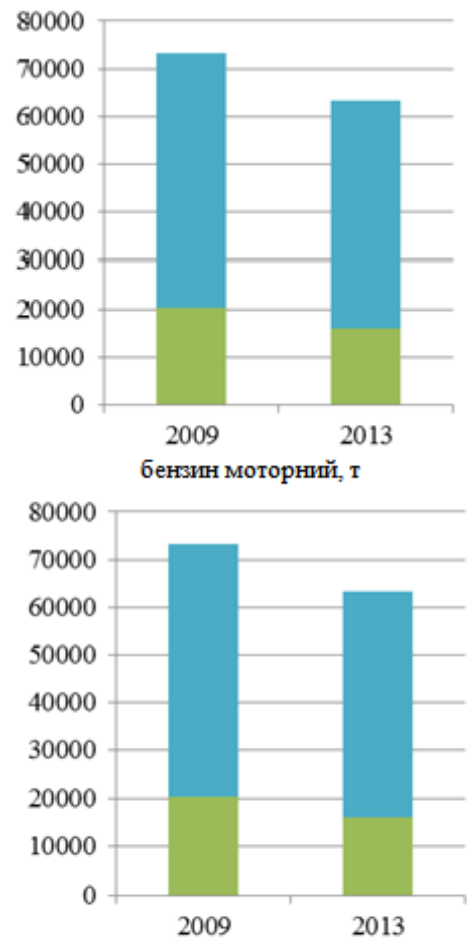

дизильне паливо, $\mathrm{T}$
" на перетворення в інші види палива та енергіi

Рис. 3. Динаміка обсягів споживання різних видів паливних ресурсів у Рівненській області за напрямками (побудовано за [3], [4]) 
кількості вугілля, що споживалося у області у 2013 року у порівнянні із 2009 у 3,5 рази при одночасному скороченні витрат вугілля для перетворення у інші види палива майже вдвічі.

У розрізі адміністративно-територіальних одиниць найбільше вугілля у 2009 році споживало місто Рівне - 21\% усього вугілля, Володимирецький район - 13\% та Дубровицький - 11\%. До 2013 року ці показники суттєво знизились і не перевищували $1 \%$, натомість 85\% усього вугілля зараз припадає на Здолбунівський район.

Така різка зміна структури споживання вугілля в області спричинена збільшення обсягів використання вугілля у якості палива для здолбунівського цементного заводу. Так, у 2013 році у промисловості було використано понад 90\% усього вугілля, ще 5\% - підприємствами та організаціями для опалення та 3,3\% - у сільському господарстві.

Загалом по області рівень споживання вугілля значно нижчий, ніж у середньому по Україні - у розрахунку на одну особу цей показник менший у 10 разів, оскільки у області відсутні власні поклади вугілля.

Одним із небагатьох видів власних паливних ресурсів Рівненщини $є$ тор неагломерований торф тут використовується на перетворення у інші види палива та енергії і відчутна динаміка даного показника за роками відсутня. Проте, досить суттєво зростає кількість спожитого торфу - із 2009 до 2013 року у 3,6 рази.

У структурі загального обсягу використаного у Рівненській області палива у перерахунку на умовне паливо частка неагломерованого торфу становить 3\% (тоді як у 2009 році - лише 1\%) і особливо відчутно його роль зросла у перетворенні на інші види енергії - із 3 \% у 2009 до 12 \% у 2013 році.

Цікаво, що майже весь неагломерований торф у області споживається лише у Дубенському районі (98 \%) та місті Дубному (2\%). I так само, майже весь, він використовується у переробній промисловості. Для населення цей вид палива не продають.

Натомість, понад половини обсягів брикетів та напівфабрикатів торфових припадає на споживання населенням, хоча із 2009 року цей обсяг скоротився майже вдвічі.

У господарській діяльності області даний вид палива у Рівненській області на 80 \% використовують для перетворення у інші види палива та енергії, a решту - на кінцеве споживання. Обсяги його споживання із 2009 року зросли майже вдвічі.

У структурі загального обсягу використаного у Рівненській області палива у перерахунку на умовне паливо його частка становить лише $1 \%$, а у перетворенні у інші види палива та енергії - 3\%.

У розрізі адміністративно-територіальних одиниць найбільше торфових брикетів та напівбрикетів споживав Сарненський район (20\%), Дубровицький (17\%) та Володимирецький (14\%).

Понад $63 \%$ усього палива даного виду використовують організації та підприємства для опалення і ще $35 \%$ - у промисловості.
Іншим власним паливним ресурсом області $\epsilon$ дрова. У економічній сфері області чверть обсягу дров припадає на кінцеве споживання, а решта - на перетворення у інші види палива чи енергії. Проте на використання у господарстві припадає лише третина, а дві третини - на продаж населенню і цей показник є стабільним.

У структурі обсягу використаного у Рівненській області палива (без відпущеного для населення) у перерахунку на умовне паливо частка дров із 2009 року скоротилася вдвічі - із 2\% до 1\%.

У розрізі адміністративно-територіальних одиниць показники із 2009 року майже не змінились і чверть використаних у господарстві області дров припадає на Рокитнівський район. Також його частка висока у Дубровицькому (12\%), Сарненському та Володимирецькому (по 11\%) районах.

За видами економічної діяльності понад 37\% дров використовують підприємства та організації, ще стільки ж - промисловість і 23,6\% - сільське господарство.

Топкові мазути на Рівненщині використовують лише у господарстві. У структурі обсягу використаного у Рівненській області палива (без відпущеного для населення) у перерахунку на умовне паливо частка мазуту майже не відчутна і становить близько 0,06\%. Майже весь мазут використовують у промисловості для кінцевого споживання (88\%) чи у якості сировини (12\%). Обсяги його споживання стрімко скорочуються - у 2013 році обсяг споживання топкового мазуту становив лише $15 \%$ від показника 2009 року.

Так, у 2009 році 38\% спожитого мазуту припадало на місто Рівне, 26\% - на Дубровицький, 20\% - на Володимирецький, $10 \%$ - на місто Кузнецовськ i 5\% на Рокитнівський район. До 2013 року від його споживання відмовились всі райони окрім Кузнецовська. А почав використовувати Гощанський район (9\%).

Надзвичайно важливе місце для розвитку господарства будь-якого регіону мають доступні паливно-мастильні матеріали, найпопулярнішими серед яких є бензин, дизельне паливо та скраплений газ.

У загальній структурі споживання бензину у області на продажі населенню припадає 75\%. У економічній сфері області майже весь бензин використовується для кінцевого споживання із 2009 року обсяги знизились на 10\%. У структурі обсягу використаного у Рівненській області палива (без відпущеного для населення) у перерахунку на умовне паливо частка бензину становить 3\%. Із 2009 року цей показник зріс на 1\%. У кінцевому споживання палива у області він займає 5\%. Понад 40\% усього спожитого бензину припадає на місто Рівне, ще по 10\% припадає на Рівненський та Сарненський райони. За видами економічної діяльності майже по 30\% припадає на сільське господарство та на використання підприємствами та організаціями і ще $27 \%$ - на промисловість.

Половина усього спожитого у області дизельного палива припадає на продажі населенню. У економіч- 
ній сфері області майже все ДП використовується для кінцевого споживання із 2009 року обсяги зросли на $20 \%$.

У структурі обсягу використаного у Рівненській області палива (без відпущеного для населення) у перерахунку на умовне паливо частка ДП становить $10 \%$ і з 2009 року цей показник майже не змінився. У кінцевому споживанні палива у області він займає 20\%. У розрізі адміністративно-територіальних одиниць 34\% спожитого ДП припадає на місто Рівне, $14 \%$ - на Здолбунівський район, 9\% - на Млинівський і 8\% - на Сарненський.

За видами економічної діяльності: $34 \%$ споживає транспорт та зв'язок, 29\% - на сільське господарство, $23 \%$ - на промисловість.

Обсяги споживання пропану $і$ бутану скрапленого у області різко скоротились - аж на дві третини. Більшу його частину споживають у господарстві 66\%, хоча ще у 2009 році 87\% відпускали населенню (обсяги продажу для населення у 2013 році становили 13\% від показника 2009 року), а у господарстві для кінцевого споживання - навпаки - зросли на $32 \%$. У структурі обсягу використаного у Рівненській області палива (без відпущеного для населення) у перерахунку на умовне паливо частка пропану та бутану скрапленого дуже незначна і становить $0,3 \%$.

Майже $40 \%$ використаного скрапленого газу припадає на Рівне і ще 20\% - на Рівненський район. У багатьох районах його взагалі не використовують. Найбільше його використовують у промисловості $60 \%$, у діяльності підприємств і організацій - 21\% та у сільському господарстві - 17\%.

У територіальному аспекті, як видно на рис. 4, понад половини усіх енергоносіїв у перерахунку на умовне паливо у області споживає місто Рівне. Також висока частка у межах області за показниками витрат енергоресурсів припадає на місто Кузнецовськ, проте це пов'язано безпосередньо із його виробничою спеціалізацією.

Порівняно високими ці показники також $є$ у центральних районах, де концентруються промислові підприємства - Здолбунівський, Рівненський, Дубенський та Костопільський райони.

Найнижчі показники витрат енергоресурсів притаманні для периферійних районів із низьким рівнем розвитку промисловості.

Проте такий територіальний аналіз стосується швидше абсолютних показників, а у перерахунку на одного жителя за кількістю спожитих у 2013 році енергоносіїв райони та міста обласного підпорядкування (Рівне та Кузнецовськ) області можна поділити на наступні групи:

- із максимальними показниками споживання енергоресурсів - місто Кузнецовськ (11,6 т у.п. на одну особу). Хоча зрозуміло, що такий показник не відображає реального їх використання, а вказує на спеціалізацію міста;

- із високим рівнем використання енергоносіїв - місто Рівне (5,65 т у.П. на 1 ос.) та Здолбунівський район (4,61 т у.п. на 1 ос.);

- із середнім рівнем використання енергоносіїв - Рівненський $(1,6)$, Костопільський $(1,54)$ та
Дубенський $(1,41)$ райони;

- із нижчим за середній рівнем використання енергоносіїв - Рокитнівський $(0,73)$ та Березнівський $(0,5)$;

- із низьким рівнем використання енергоносіїв від 0,2 до 0,5 т у.п. на одну особу: Володимирецький, Гощанський, Дубровицький, Зарічненський, Млинівський, Радивилівський, Сарненський;

- із найнижчим рівнем використання енергоносіїв - Демидівський $(0,13)$, Корецький та Острозький (по 0,18).

Набувають значної популярності у області різні види альтернативних паливних ресурсів, такі як паливні гранули, які виготовляють із відходів лісозаготівельної та деревообробної промисловості. У області налічується вже близько десяти виробників такого палива, що постійно збільшують обсяги виробництва, проте статистичної інформації про обсяги їх споживання наразі немає, як і немає інформації про використання біопалива (біомаси), що також набуває популярності у регіоні.

Взагалі в Україні відновлювані джерела енергії (ВДЕ) становлять лише 4 \%, тоді як в країнах Європи більше 10\%: енергія біомаси, гідроенергетика, комунальні відходи, енергія вітру, фотоелектричні джерела енергії, сонячне випромінювання i геотермальна енергія. Частка кожного виду в енергобалансі різна.

Понад половину від загального виробництва відновлюваних джерел енергії становить біомаса. Найбільше енергії з біомаси виробляють у Франції, Швеції та Фінляндії. В Україні у 2001 році розроблено «Концепцію розвитку біоенергетики в Україні». На дослідних ділянках інституту сільського господарства Західного Полісся під час спостереження за ростом різних енергетичних культур - міскантуса, топінамбура, кукурудзи, верби, тополі, тростини, було помічено, що в широтах Рівненської області, зважаючи на природні умови та стан сільськогосподарських угідь, для отримання твердих біопалив підходять в основному верби i тополі, а також їхні гібриди.

За попередніми розрахунками, якщо засадити вербою хоча б десяту частину непродуктивних сільськогосподарських земель Рівненської області (12 тис га), то через три роки можна отримати 264 тис тонн сухої речовини верб. У 2010 році Рівненська обласна рада затвердила Програму вирощування саджанців енергетичної верби в Рівненській області, в якій було заплановано, що з 2012 року на Рівненщині буде вирощуватися понад 1 млн 600 тис саджанців енергетичної верби, що забезпечить власним посадковим матеріалом 80-100 га промислових плантацій, а також створить умови для розширення площ розсадника для розмноження цієї культури. Програма також гарантувала фінансове забезпечення проекту. На Рівненщині також реалізовується проект «Створення біоенергетичного парку енергетичної верби» за підтримки Програми малих грантів Глобального екологічного фонду Програми розвитку ООН в Україні. Його виконавцями є Громадська організація «Рівненський центр 


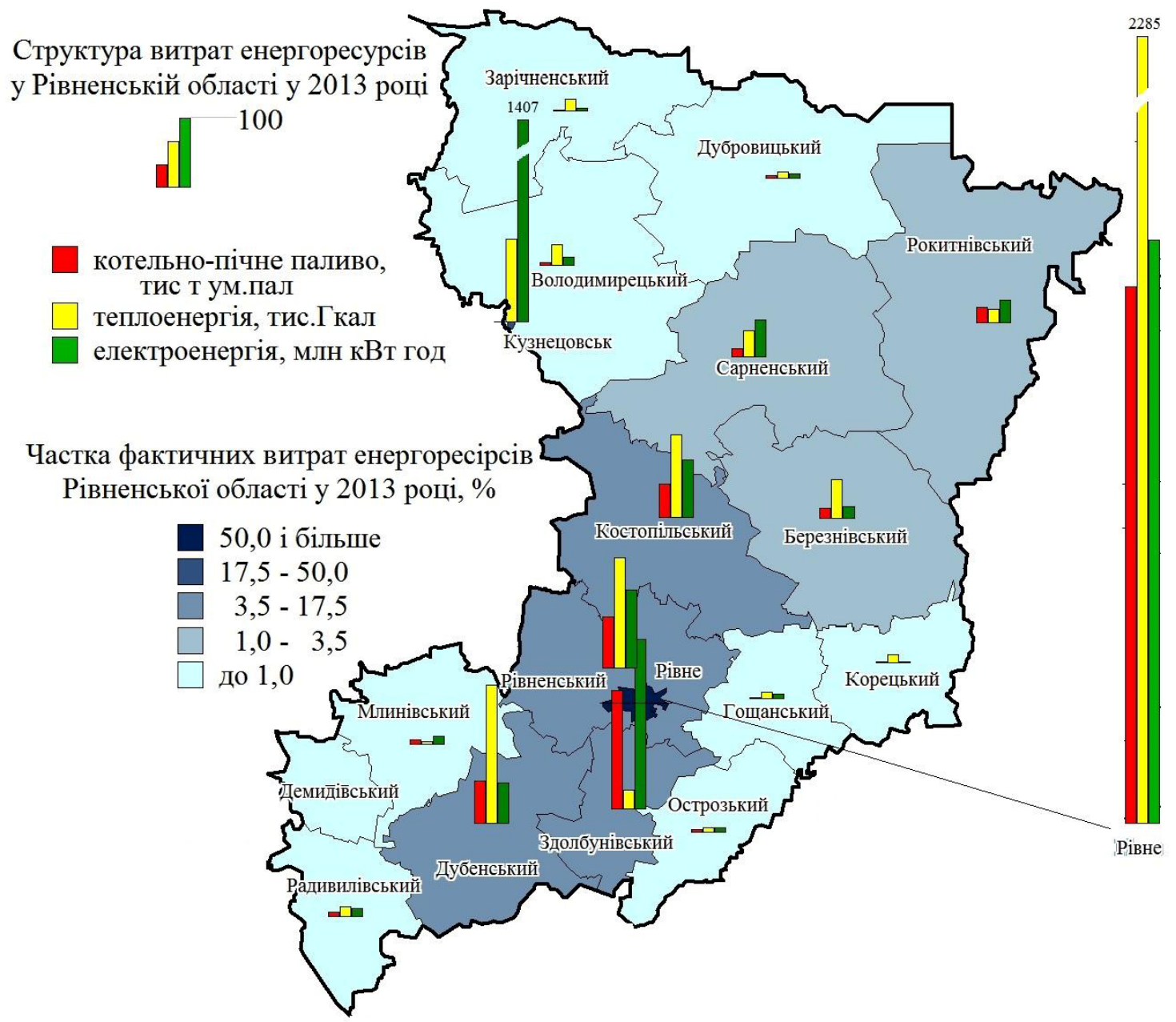

Рис. 4. Фактичні витрати енергоресурсів по території Рівненської області у 2013 році

маркетингових досліджень» та Приватне акціонерне товариство «Рівненська рибоводно-меліоратина станція».

Верба доволі цінний вид біомаси. Так 1 тонна енергетичної верби заміняє 1,12 т соломи, 0,43 т ріпакової олії, 460 кг викопного вугілля, 800 кг бурого вугілля, 0,37 т мазуту, $730 \mathrm{~m}^{3}$ біогазу, $510 \mathrm{~m}^{3}$ природного газу. Тепловіддача від спалювання 1 тонни деревини енергетичної верби становить 16 МДж/кг, тоді як від дубових дров - 14,1 МДж/кг, від соснових - 13,8 МДж/кг, від 1 тонни соломи 14,3 МДж/кг.

Вирощування верби - процес, тривалий у часі. Перший «урожай» можна збирати на 3 рік вирощування. 31 га можна зібрати 20-30 тон біомаси. На одному полі вирощувати вербу можна 21-25 років. Загалом верба не дуже вибаглива щодо обробітку. Головним залишається посадка і догляд за живцями на першому році вирощування.

Фермери Рівненщини зацікавились питаннями переробки енергетичної верби на брикети чи пелети, адже це може принести неабиякий прибуток. Вже в 2012 році енергетичні верби висаджено на 26 га промислових плантацій, відведених у 5-ти поліських районах області - Березнівському (4 га), Володимирецькому (9 га), Дубровицькому (5 га), Костопільському (5 га), Рокитнівському (3 га).
Загалом висаджено 517 тис саджанців. Тому вже через кілька років сподівалися чекати буму розвитку біоенергетики в регіоні.

Проте, плантація енергетичної верби, якою засадили чотири гектари на Рівненській сільськогосподарській дослідній станції у Шубкові, не виросла й ніяких врожаїв тут не зібрали, а проект вирощування енергетичної верби зараз заморожений, бо не з'ясованою є технічна його сторона. Оскільки біля вербового поля мав би бути комплекс зі збирання та переробки цієї енергетичної сировини.

Енергія, отримана завдяки переробці комунальних відходів, становить близько 6\% загальних обсягів ВДЕ. Найбільше їі виробляють в Німеччині, Франції, Данії та Голландії. У 2009 році поблизу Рівного почав діяти перший у Західному регіоні України сміттєпереробний завод, продукція якого мала б замінити природний газ при промисловому виробництві цементу на ПАТ «Волинь-Цемент», проте оскільки таке підприємство є унікальним, то через відсутність механізму ліцензування його діяльності підприємство припинило свою роботу.

Рівненщина $є$ одною із найбільш заліснених територій. Лісом вкрито 36\% території області. Запаси відходів деревини від її заготівлі за даними експертів складають більше 100 тис $\mathrm{M}^{3}$ в рік. На території області відходи деревини активно 
використовуються для виробництва брикетів та пелет. Міська влада Рівного планує перевести 3 міські котельні на опалення деревинними відходами, що допоможе місту отримувати гарячу воду протягом літнього сезону. Слід зазначити, що активізувати використання біомаси у енергетичному балансі почали, створюючи відповідні державні програми, які надають можливість компенсувати витрати, які несуть підприємства та населення на переобладнання котлів та іншого устаткування.

Одним із найбільш ефективних видів альтернативного палива для Рівненщини є деревні пелети. Популяризатором пелет в Свропі вважається Швеція, яка почала виробництво гранул 3 відходів деревообробної промисловості в 1985 році. Виробництво і продаж їх в Україні перебуває на початковому рівні розвитку i у найближчому майбутньому продаж пелет 3 року в рік зростатиме за рахунок того, що цей вид палива має багато переваг. Вони виділяють більше тепла, ніж тирс і тріски, збільшуючи коефіцієнт корисної дії котелень, не вимагають великих складських площ. До складу пелет, крім деревних відходів, також може входити торф та відходи сільськогосподарського виробництва.

Гранули виробляються без хімічних закріплювачів під високим тиском. Теплотворна здатність деревних гранул становить 4,3-4,5 кВТ/ кг. При спалюванні 1 т деревних гранул виділяється стільки ж енергії, скільки при спалюванні 1,6 т деревини, $480 \mathrm{~m}^{3}$ газу, 500 л дизельного палива або 700 л мазуту. При цьому деревні гранули набагато екологічніші від традиційного палива: у 10-50 разів нижче викиди вуглекислого газу, в 15-20 разів менше відходів золи ніж при спалюванні вугілля. Витрати енергії на виробництво деревних гранул складають приблизно 3 \% від вмісту енергії, що набагато нижче витрат на отримання природного газу чи мазуту.

В умовах недостатнього забезпечення України власними енергетичними ресурсами, використання відходів деревини стає одним із найбільш доступних, економних та перспективних альтернативних джерел енергоресурсів, зокрема для обігрівання приватих будинків та для комунальних підприємств.

Таким чином, виробництво пелет для Рівненської області може бути стратегічним експортним напрямком. Так, Данія для забезпечення власних потреб імпортує 48\% пелет, Німеччина - 37\%, Італія $-27 \%$, Швеція - 14\%.

Висновки і перспективи подалыших розвідок. У використанні паливних ресурсів у Рівненькій області спостерігаються тенденції до збільшення кількості їх споживання, проте це розширення здійснюється в основному за рахунок власних (чи хоча б вітчизняних) ресурсів - вугілля, торф, дрова. Це є дуже важливим, адже у перерахунку на умовне паливо понад 80\% паливних ресурсів, що споживаються у області, є імпортними (природний газ, дизельне паливо, бензин та інші), що спричиняє негативний вплив на економічну безпеку регіону. По території області споживання паливних ресурсів значно відрізняється: значна їх частка споживається у промислових вузлах - Кузнецовському, РівненськоЗдолбунівському, Костопільському та Дубенському, у яких споживають понад дві третини усіх спожитих у області паливних ресурсів. У периферійних сільськогосподарських районах даний показних $\epsilon$ найнижчим. Сучасні зміни, що відбуваються у всіх ланках країни та регіону, безумовно призведуть і до подальших змін у структурі споживання енергоносіїв i те, як економіка регіону зможе відреагувати та пристосуватися до нових умов обов'язково відобразиться на ефективності та успішності його подальшого господарського розвитку.

\section{References:}

1. Mel'nik L. V. Pašečko O. A. Porìvnâl'nij analìz zabezpečenostì energetičnimi resursami regìonu [Comparative analysis of energy resources of the region]. Problemi racional'nogo vikoristannâ social'no-ekonomičnogo ta prirodnoresursnogo potencialu regionu: finansova politika ta investicii [Problems of rational use of regional socio-economic and natural-resource potential: financial policy and investments], 2013, Vol. 19, N 4, pp. 263-272. (In Ukrainian).

2. Rejting energoefektivnosti Ukraïni [The energy efficiency rating of Ukraine]. Access mode: http://energyindex.scm.com.ua (In Ukrainian).

3. Statističnij zbìrnik "Palivno-energetičnì resursi Rìnnensinini u 2013 rocì" [Statistical Yearbook "Fuel and energy resources of Rivne region (2013)"']. Main Administration of Statistics in Rivne Region, 2014, 36 p. (In Ukrainian).

4. Statističnij zbìrnik "Palivno-energetičnì resursi Rìnensinini u 2009 rocì" [Statistical Yearbook "Fuel and energy resources of Rivne (2009)"']. Main Administration of Statistics in Rivne Region, 2010, 36 p. (In Ukrainian). 